\title{
Evaluation of Eyelid Tumor Cases at Our Clinic
}

\section{Kliniğimizde Gerçekleștirilen Göz Kapağı Tümörü Olgularının Değerlendirilmesi}

\begin{abstract}
$1 /$
ABSTRACT

Introduction: This study aimed to evaluate patients who presented with eyelid tumour and to evaluate the masses pathologically.

Methods: Between March 1, 2016- April 1, 2019, 2019, age, gender, eyelid side, pathological evaluation results and surgical margin status of the patients who presented to our clinic with eyelid mass were evaluated.

Results: During the study period, 212 patients with a mean age of $55 \pm 16$ years (range, $15-85$ years) who underwent surgery because of an eyelid mass were included in the study. Among these patients, 78 (37.8\%), 74 (35.9\%) and 54 (26.2\%) underwent surgery of the right, left and both eyelids, respectively, whereas 55 (26.9\%), 128 (62.7\%) and 21 (10.2\%) underwent surgery of the lower, upper and both lower and upper eyelids, respectively. A total of 376 eyelid mass surgeries were performed. Among these masses, 371 (98.6\%) were benign and 5 (1.3\%) were malignant. Regarding pathological types of benign masses, 71 (19.1\%) were seborrheic keratosis, 70 (18.8\%) were squamous papilloma, 53 (14.21\%) were fibroepithelial polyps, 52 (14.2\%) were xanthelasma, 35 (9\%) were intradermal nevus, 22 (5.9\%) were epidermoid cyst, 14 (3.8\%) were verruca vulgaris and 51 (13.7\%) were different types of tumours. Five patients were diagnosed with malignant eyelid tumours; three of them had basal cell carcinoma, one had squamous cell carcinoma and one had malignant melanoma.
\end{abstract}

Conclusion: Although eyelid tumours are mostly benign tumours, malignant tumours may be present in some cases. Pathological evaluation of valve masses obtained surgically is important to determine the prognosis of patients.

Keywords: Eyelid tumour, eyelid, pathological assessment

\section{öZ}

Amaç: Kliniğimize göz kapağı tümörü şikayeti ile başvuran olguların ve kitlelerin patolojik olarak değerlendirilmesi amaçlanmıştır.

Yöntemler: 01.03.2016 ve 01.04.2019 tarihleri arasında kliniğimize göz kapağı kitlesi şikayeti ile başvuran hastaların yașları, cinsiyetleri, hangi göz kapağı olduğu, kitlelerin patolojik değerlendirme sonuçları, cerrahi sınır durumları ile klinik devamlılığı değerlendirildi.

Bulgular: Göz kapağında kitle nedeni ile ameliyat edilen yaş

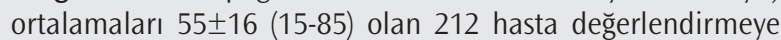
alındı. Çalıșmaya dahil edilen hastaların 78 'inin $(\% 37,8)$ sağ göz kapağından, 74'ünün $(\% 35,9)$ sol göz kapağından ve 54'ünün $(\% 26,2)$ hem sağ hem de sol göz kapağından kitle eksizyonu yapıldı. Hastaların $55^{\prime}$ inin $(\% 26,9)$ alt göz kapağından, 128’inin $(\% 62,7)$ üst göz kapağından ve 21'inin $(\% 10,2)$ hem alt hem de üst göz kapağından toplam 376 adet göz kapağı kitlesi ameliyat ile alınmıștır. Alınan kitlelerin 376'sı $(\% 98,6)$ benign, 5’i $(\% 1,3)$ malign özellikte olarak patolojik olarak raporlanmıștır. Benign karakterdeki kitlelerden, 71 tanesi $(\% 19,1)$ seboreik keratoz, 70 tanesi $(\% 18,8)$ skuamöz papillom 53 tanesi $(\% 14,21)$ fibroepitelyal polip, 52 tanesi ksentelazma (\%14,2), 35 tanesi (\%9) intradermal nevus, 22 tanesi $(\% 5,9)$ epidermal kist, 14 tanesi $(\% 3,8)$ verruka vulgaris ve 51 tanesi $(\% 13,7)$ farklı tiplerde tümörler olarak raporlanmıştır. Hastaların 5 tanesinden 3 tanesinde bazal hücreli karsinom olmak üzere birer skuamöz hücreli karsinom ve malign melanom tiplerinde malign karakterde kapak tümörleri elde edilmiștir.

Sonuç: Kapak tümörleri çoğunlukla benign karakterde tümörler olmakla birlikte, bazı olgularda malign karakterde tümörler de olabilir. Ameliyat ile alınan kapak kitlelerinin patolojik olarak değerlendirilmesi hasta prognozu açısından önemlidir.

Anahtar Kelimeler: Kapak tümörü, göz kapağı, patolojik değerlendirme

Cite this article as/Atıf: Zırtıloğlu S, Alıkma MS, Bulut E. Evaluation of Eyelid Tumor Cases at Our Clinic. İstanbul Med J 2020; 21(4): 258-61.

(C) Copyright 2020 by the University of Health Sciences Turkey, Istanbul Training and Research Hospital/Istanbul Medical Journal published by Galenos Publishing House

(C) Telif Hakkı 2020 Sağıı Bilimleri Üniversitesi Istanbul Ĕgitim ve Araştırma Hastanesi/Istanbul Tıp Dergisi, Galenos Yayınevi tarafından basılmıștır. 


\section{Introduction}

Tumors of the skin and skin appendages can be observed throughout the body, but are often observed in the head and neck area and eyelids (1). Eyelid tumors occur in $5 \%$ and $10 \%$ of superficial skin tumors throughout the body (2). Eyelid tumors have a high proportion within eyelid pathologies $(3,4)$. These tumors are more likely to be benign tumors than malignant tumors $(3,5,6)$. However, both benign and malignant eyelid tumors are most likely to originate from epidermal cells (7).

Eyelid tumors may also accompany systemic diseases (8). Hemotological malignancies such as non-hodking lymphoma, hodking lymphoma and chronic lymphocytic leukemia increase in benign and malignant tumoral formations of the eyelid $(2,9)$. However, the increase in eyelid tumors is also observed in neurofibromatosis disease (10). Treatment of eyelid tumors is performed for cosmetic purposes and for the exclusion of malignancy (11). Surgical method is preferred as a priority in treatment (12). Surgical treatment varies depending on the location, depth and area of the lesion $(13,14)$.

The aim of our study was to determine the characteristics and frequency of patients admitted to our clinic because of eyelid mass and to get an idea of the frequency of eyelid tumors in our region.

\section{Methods}

In our study, patients admitted to University of Health Sciences University Turkey, Bakırköy Dr. Sadi Konuk Training and Research Hospital Ophthalmology Outpatient Clinic between 01.03.2016 and 01.04.2019 and operated with a pre-diagnosis of eyelid mass were evaluated retrospectively. Patients with a definitive pathological diagnosis with adequate biopsy material were included in the study. The exclusion criteria were determined as patients with a history of precancerous and cancerous systemic disease in history, inflammatory formations, and failure to make a pathologically accurate diagnosis in the samples taken. The patients' ages, gender, which eyelid was observed to have tumors, the upper and lower side of the eyelid, how many eyelid masses were surgically removed and the pathological evaluation results of the eyelid mass were recorded. Ethics Committee approval was obtained from Pamukkale University Faculty of Medicine for the study (approval no: 60116787-020/11951). The study was conducted in accordance with the Helsinki Declaration.

The patients who underwent surgical treatment due to eyelid tumor were operated by the same surgeon. After surgical site cleaning with $10 \%$ povidone iodine solution, the required amount was injected with insulin injector from jethocaine hydrochloride and epinephrine (Jethocaine ${ }^{\circledR}$ Adeka) solution to increase the lesion slightly from the junction of the lesion and the intact eyelid. The lesion was macroscopically removed with scissors and scalpel in a depth so that no tumor lesions were left at the surgical border. After bleeding control was performed on the site where the lesion was taken, the intact skin was sutured with 8.0 vikril yarn. The removed eyelid tumor was referred for pathological examination. All patients were prescribed topical fusidic acid (Fusix ${ }^{\circledR}$ -Abdi Ibrahim) for post-operative protection. All patients were called for control at 1 week (5-9 days) after the operation. As the surgical margin was found to be clean, and the malignancy was not suspected according to the pathological evaluation; patients' postoperative followup was terminated right after the removal of the sutures planted during the operation. In all cases, the patients who were diagnosed with malignancy in the pathology report were referred to a superior center for further examination and treatment.

\section{Statistical Analysis}

Statistical evaluation, using the SPSS 25.00 for Windows software (SPSS Inc., Chicago, Illinois, USA), was given as number and percentage for categorical variables.

\section{Results}

A total of 212 patients were enrolled in the study, including 99 men (46.7\%) and 113 women (53.3\%) with an average age of 55 \pm 16 (15-85). Tumor excision was performed by 78 (37.8\%) right eyelid, 74 (35.9\%) left eyelid and 54 (26.2\%) both right and left eyelid of the patients who participated in the study. Tumor excision was performed on 55 (26.9\%) lower eyelid, 128 (62.7\%) upper eyelid, and 21 (10.2\%) lower and upper eyelid. A total of 376 eyelid tumors, an average of 1.8 \pm 1.5 (1$10)$, were removed from the patients evaluated in the study, and were pathologically evaluated. According to the results of the pathological evaluation, the frequency of the masses received was reported (Table 1). When the obtained masses were examined, it was determined that 371 (98.7\%) eyelid masses were of benign character and 5 (1.3\%) eyelid masses were of malignant character. When all patients were examined, $376(98.6 \%)$ of the patients had benign masses and $5(1.3 \%)$ had malignant masses (Table 1).

In our study, 70 squamous papillomavirus histology masses were removed from 39 patients, 22 of whom were male and 17 of whom were female. The most common accompanying eyelid tumor was seboraic keratosis in patients with squamous papillomavirus excised. Seboraic keratosis was excised from 11 patients (28.2\%) with squamous papilloma. In patients with squamous papillomavirus, the second most common accompanying eyelid tumor was the intradermal nevus Intradermal nevus was detected in 2 patients (5.1\%) with squamous papillomavirus.

In our study, masses with 71 seboraic keratosis histology were removed from 41 patients, 22 of whom were male and 19 of whom were female. Masses diagnosed with squamous papillomavirus were found in 11 (26.8\%) of patients with seboraic keratosis. Fibroepithelial polyps were found to be the second most commonly associated eyelid tumor in patients with seboraic keratosis. Fibroepithelial polyps were detected in 5 patients (12.1\%) with seboraic keratosis.

In 4 out of 5 patients with malignant mass on the eyelid, surgical mass limits were reported as positive or inadequate. These two patients were referred to an superior center with an oncology unit for further examination and treatment. In 30 patients with benign mass on the eyelid, the limits of surgical material were reported positively in 11 out of 35 intradermal nevus cases (33\% of the patients). In these patients, the surgical limit was extended with the second session resection and the medical intervention was terminated. 


\begin{tabular}{|c|c|}
\hline Diagnosis & n (\%) \\
\hline Seborrheic keratosis & $71(18.8)$ \\
\hline Squamous papilloma & $70(18.6)$ \\
\hline Fibroepithelial polyps & $53(14)$ \\
\hline Xanthalesma & $52(13.8)$ \\
\hline Nevus, intradermal & $35(9)$ \\
\hline Cyst, epidermal & $22(5.8)$ \\
\hline Verruca vulgaris & $14(3.7)$ \\
\hline Hydrocystoma & $6(1.5)$ \\
\hline Hyperkeratotic verrucous hyperplasia & $6(1.5)$ \\
\hline Cyst, vellus & $4(1)$ \\
\hline Seborrheic keratosis, acanthotic type & $4(1)$ \\
\hline $\mathrm{BCC}^{*}$ & $3(0.7)$ \\
\hline Trichoepithelioma & $3(0.7)$ \\
\hline Actinic lentigo & $2(0.5)$ \\
\hline Kist, Trichilemmal & $2(0.5)$ \\
\hline Lobular capillary hemangioma & $2(0.5)$ \\
\hline Nevus, compaund & $2(0.5)$ \\
\hline Nevus, epidermal & $2(0.5)$ \\
\hline Pyogenic granuloma & $2(0.5)$ \\
\hline Subepidermal calcified nodule & $2(0.5)$ \\
\hline Verrucous hyperplasia & $2(0.5)$ \\
\hline Actinic keratosis & $1(0.3)$ \\
\hline Clear cell acanthoma & $1(0.3)$ \\
\hline Inverted follicular keratosis & $1(0.3)$ \\
\hline Ceratoacanthoma & $1(0.3)$ \\
\hline Lichen planus-like keratosis & $1(0.3)$ \\
\hline Malignant melanoma & $1(0.3)$ \\
\hline Molluscum contagiosum & $1(0.3)$ \\
\hline Neurome & $1(0.3)$ \\
\hline Seborrheic keratosis, irrite type & $1(0.3)$ \\
\hline Squamous carcinoma & $1(0.3)$ \\
\hline Soft fibroma & $1(0.3)$ \\
\hline Foreign body reaction & $1(0.3)$ \\
\hline
\end{tabular}

\section{Discussion}

Tumors originated from epidermal cells are the most commonly observed benign eyelid tumors. In a study performed by Yu et al. (7), benign tumors of epidermal cell origin were listed as seboraic keratosis, squamous papillomavirus, epidermal cyst and dermoid cyst in order to be seen from the most to the least. In a study conducted by Karabulut et al. (1), they identified the most common benign eyelid tumor as the melanocytic nevus. Çağlar et al. (15), Göncü et al. (16) and Obata et al. (6) indicated the most common benign eyelid tumor as a nevus in their studies. Deprez and Uffer (17), Gundogan et al. (18), Kurt et al. (19) indicated the most common benign eyelid tumors as squamous papillomavirus and seboraic keratosis, respectively. In our study, the most common benign eyelid tumor was seborrhaic keratosis followed by squamous papillomavirus. Although Göncü et al. (16) observed squamous papillomavirus and seborrhaic keratosis less frequently in their studies, they showed both tumors among the most common tumors. Obata et al. (6) also identified the second most common benign eyelid tumor as seborrhaic keratosis. It is observed that the results of our study are compatible with other studies. Excision is prioritised because seborrheic keratosis is able to mimic malignant tumors despite being of benign character.

Göncü et al. (16), Ho et al. (20), Yu et al. (7), Asproudis et al. (21) and Pe'er (22) indicated that benign eyelid masses are more often observed in the upper eyelid. Coroi et al. (23) noted that eyelid tumors of benign character are more common in the lower eyelid. In our study, benign eyelid tumors were observed more in the upper eyelid. Göncü et al. (16), Kurt et al. (19), Hassan and Nelson (4) indicated that benign eyelid masses affect the right and left eye in approximately equal rate. Similarly, in our study, benign eyelid tumors were found to affect right $(n=76,37.4 \%)$ and left $(n=73,35.9 \%)$ eyelids at a similar rate [right: 76 (37.4\%), left: $73(35.9 \%)]$.

Salomon et al. (24) remarked that eyelid tumors were observed mostly in patients aged 60 and over. Jahagirdar et al. (25) also indicated that eyelid tumors were observed more at an advanced age. Age averages were 58.1 \pm 14.9 (15-82) in patients with squamous papilloma; $62.4 \pm 10.9$ (32$81)$ in patients with seborrhaic keratosis; $54.3 \pm 14.4$ (34-85) in patients with xentelasma; and $58.5 \pm 14.6$ (23-84) in patients with fibroepithelial polyps. In our study, similar to these studies, it was determined that eyelid tumors were observed more in advanced age.

Asproudis et al. (21) noted that eyelid masses of malignant character were more likely to be seen on the lower eyelid. Wang et al. (26), Gundogan et al. (18), Silverman and Shinder (2) and Nuhoglu et al. (27) identified the most common malignant eyelid tumor as basal cell cancer. In our study, the number of cases with malignant eyelid mass excised was low, so it could not be compared with other studies.

The limitation in the study was that no excisional biopsy accompanied by frozen was performed because there was no suspicion of malignancy in the included patients. Therefore, our rate of patients with pathological positive surgery limits was found to be high.

Although we have a patient diagnosed with actinic keratosis, it is important because it is a premalignant lesion and it is not always clinically differential diagnosis with squamous cell carcinoma (28). Although we have two patients diagnosed with solar lentigo, excision is required in these lesions as malignancy cannot be completely ruled out in dermoscopical examinations in these tumors with facial placement (29).

Although the mass frequency of patients in very large populations in China and Taiwan has been looked at, there is a need for wider population studies in our country $(30,31)$.

\section{Conclusion}

Although the character of eyelid masses is generally benign, it can also be in the malignant character. Although the purpose of surgical 
treatment of this disease which affects more advanced ages is cosmetic, in some cases malignancy is excluded. It is extremely important to evaluate the eyelid masses pathologically after removal.

\section{Ethics}

Ethics Committee Approval: Ethics Committee approval was obtained from Pamukkale University Faculty of Medicine for the study (approval no: 60116787-020/11951).

Informed Consent: Informed consent was obtained from all patients.

Peer-review: Externally peer-reviewed.

Authorship Contributions: Surgical and Medical Practices - M.S.A.; Concept - S.Z., M.S.A.; Design - S.Z., M.S.A.; Data Collection or Processing - S.Z., M.S.A., E.B.; Analysis or Interpretation - S.Z.; Literature Search S.Z., M.S.A., E.B.; Writing - S.Z., M.S.A.

Conflict of Interest: No conflict of interest was declared by the authors.

Financial Disclosure: The authors declared that this study received no financial support.

\section{References}

1. Karabulut HH, Karabulut YY, Şenel E, Dölek Y, Uslu A, Kurşun N. Göz Kapă̆ Tümörlerinin Histopatolojik ve Demografik Özellikleri. Turk J Dermatol 2014; 4: 197-201.

2. Silverman N, Shinder R. What's New in Eyelid Tumors. Asia Pac J Ophthalmol (Phila) 2017; 6: 143-52.

3. Actis AG, Actis G, De Sanctis U, Fea A, Rolle T, Grignolo FM. Eyelid benign and malignant tumors: issues in classification, excision and reconstruction. Minerva Chir 2013; 68: 11-25

4. Hassan AS, Nelson CC. Benign eyelid tumors and skin diseases. Int Ophthalmol Clin 2002; 42: 135-49.

5. Pe'er J. Pathology of eyelid tumors. Indian J Ophthalmol 2016; 64: 177-90.

6. Obata H, Aoki Y, Kubota S, Kanai N, Tsuru T. Incidence of benign and malignant lesions of eyelid and conjunctival tumors. Nippon Ganka Gakkai Zasshi 2005; 109: 573-9.

7. Yu SS, Zhao Y, Zhao H, Lin JY, Tang X. A retrospective study of 2228 cases with eyelid tumors. Int J Ophthalmol 2018; 11: 1835-41.

8. Shome D, Bell D, Esmaeli B. Eyelid carcinoma in patients with systemic lymphoma. J Ophthalmic Vis Res 2010; 5: 38-43.

9. Kyasa MJ, Hazlett L, Parrish RS, Schichman SA, Zent CS. Veterans with chronic lymphocytic leukemia/small lymphocytic lymphoma (CLL/SLL) have a markedly increased rate of second malignancy, which is the most common cause of death. Leuk Lymphoma 2004; 45: 507-13.

10. Avery RA, Katowitz JA, Fisher MJ, Heidary G, Dombi E, Packer RJ, et al. Orbital/ periorbital plexiform neurofibromas in children with neurofibromatosis type 1: multidisciplinary recommendations for care. Ophthalmology 2017; 124 : 123-32.

11. Zielinski T, Pisera P, Siewiera I, Sporny S, Iljin A. [Surgical treatment of malignant eyelid tumors]. Pol Merkur Lekarski 2013; 34: 214-8.

12. Wójcicki P, Zachara M. Surgical treatment of eyelid tumors. J Craniofac Surg 2010; 21: 520-5.
13. Dailey RA, Chavez MR. Upper eyelid margin mass excision technique: supraciliary approach. Ophthalmic Plast Reconstr Surg 2011; 27: 48-51.

14. Fan B, Liu JJ, Wang BF, Sun YJ, Li GY. Case report repairing orbital skin defects using composite flaps after giant eyelid-derived tumor excision and orbital exenteration. Medicine Baltimore 2017; 96: e8978.

15. Çağlar Ç, Güney G, Dönmez O, Baş Y, Durmuş M. Göz Kapă̆ı Tümörlerinde Histopatoloji Sonuçları. Turkiye Klinikleri J Ophthalmol 2017; 26: 25-31.

16. Göncü $T$, Çakmak $S$, Akal A, Oğuz $H$. Iyi huylu göz kapağı tümörlerinin klinikopatolojik özellikleri: 101 olgunun retrospektif analizi. Turk J Ophthalmol 2014; 44: 384-7.

17. Deprez M, Uffer S. Clinicopathological features of eyelid skin tumors. A retrospective study of 5504 cases and review of literature. Am J Dermatopathol 2009; 31: 256-62

18. Gundogan FC, Yolcu U, Tas A, Sahin OF, Uzun S, Cermik H, et al. Eyelid tumors: clinical data from an eye center in Ankara, Turkey. Asian Pac J Cancer Prev : APJCP 2015; 16: 4265-9.

19. Kurt A, Mutlu SN, Yener Hi, Bayram N, Nazlım S. Primer göz kapağ tümörlerinde histopatoloji sonuçları. Dicle Med J 2015; 42: 72-7.

20. Ho M, Liu DT, Chong KK, Ng HK, Lam DS. Eyelid tumours and pseudotumours in Hong Kong: a ten-year experience. Hong Kong Med J 2013; 19: 150-5.

21. Asproudis I, Sotiropoulos G, Gartzios C, Raggos V, Papoudou-Bai A, Ntountas I, et al. Eyelid tumors at the university eye clinic of Ioannina, greece: a 30-year retrospective study. Middle East Afr J Ophthalmol 2015; 22: 230-2.

22. Pe'er J. Pathology of eyelid tumors. Indian J Ophthalmol 2016; 64: 177-90.

23. Coroi MC, Roşca E, Mutiu G, Coroi T, Bonta M. Eyelid tumors: histopathological and clinical study performed in County Hospital of Oradea between 20002007. Rom J of Morphol Embryol 2010; 51: 111-5.

24. Salomon J, Bieniek A, Baran E, Szepietowski JC. Basal cell carcinoma on the eyelids: own experience. Dermatol Surg 2004; 30: 257-63.

25. Jahagirdar SS, Thakre TP, Kale SM, Kulkarni H, Mamtani M. A clinicopathological study of eyelid malignancies from central India. Indian J Ophthalmol 2007; 55: 109-12.

26. Wang CJ, Zhang HN, Wu H, Shi X, Xie JJ, He JJ, et al. Clinicopathologic features and prognostic factors of malignant eyelid tumors. Int J Ophthalmol 2013; 6: $442-7$.

27. Nuhoglu F, Abul D, Ozdemir FE, Eltutar K. Distribution of lid tumours applied surgical treatment in our clinic. MN Oftalmoloji 2013; 20: 45-9.

28. Fleming P, Zhou S, Bobotsis R, Lynde C. Comparison of the Treatment Guidelines for Actinic Keratosis: A Critical Appraisal and Review. J Cutan Med Surg 2017; 21: 408-17.

29. Evans SE, Şahin S, Özkaya O. Dermoscopic features in facial solar lentigo. Turkiye Klinikleri J Dermatol 2006; 16: 90-3.

30. Wang LY, Chen LR, Dai XZ, Cao J, Gao T, Yao K, et al. A clinicopathological classification analysis of ocular mass lesions in 7910 cases. Zhonghua Yan Ke Za Zhi 2019; 55: 847-53.

31. Huang YY, Liang WY, Tsai CC, Kao SC, Yu WK, Kau HC, et al. Comparison of the clinical characteristics and outcome of benign and malignant eyelid tumors: an analysis of 4521 eyelid tumors in a tertiary medical center. BioMed Res Int 2015; 2015: 453091. 